\title{
Queensland Fruit Fly, Bactrocera tryoni (Froggatt) (Insecta: Diptera: Tephritidae) ${ }^{1}$
}

\author{
H. V. Weems, Jr. and T. R. Fasulo ${ }^{2}$
}

\section{Introduction}

The Queensland fruit fly, Bactrocera tryoni

(Froggatt), occurs in climates ranging from temperate to tropical. Within its range, it is one of the most important pests with which pome and stone fruit growers have to contend, and at times it has been a very destructive pest of citrus. Bactrocera tryoni appears to be almost as destructive to fruit production in its Australian range as the oriental fruit fly, Bactrocera dorsalis Hendel, is in countries where it appears. A heavy outbreak of $B$. tryoni in New South Wales during 1940-41 resulted in the rejection of 5 to $25 \%$ of citrus at harvest. It is not established in the United States, but the extensive damage caused by the larvae of this fly in areas similar to Florida where it has become established indicates that this species could become a serious pest of pome and stone fruit crops, and possibly of citrus, if it were to become established in Florida.

\section{Synonymy}

Chaetodacus tryoni (Froggatt)

Dacus ferrugineus tryoni (Froggatt)

Dacus tryoni (Froggatt)

Strumeta tryoni (Froggatt)

Tephritis tryoni Froggatt

(White and Elson-Harris 1994)

\section{Distribution}

The Queensland fruit fly is distributed over about half of Australia, including parts of Queensland, New South Wales and Victoria, with outbreaks in South Australia. In 1989, B. tryoni became established in Perth, Western Australia, but an eradication campaign using baits, male lures and sterile insect techniques appears to have eradicated it. No wild flies have been collected since November 1990 (White and Elson-Harris 1994).

1. This document is EENY-259 (originally published as DPI Entomology Circular 34), one of a series of Featured Creatures from the Entomology and Nematology Department, Florida Cooperative Extension Service, Institute of Food and Agricultural Sciences, University of Florida. Published: January 2002. This document is also available on Featured Creatures Website at http://creatures.ifas.ufl.edu. Please visit the EDIS Website at http://edis.ifas.ufl.edu. Additional information on these organisms, including many color photographs, is available at the Entomology and Nematology Department website at http://entnemdept.ifas.ufl.edu/.

2. H. V. Weems, Jr., Florida Department of Agriculture and Consumer Services, Division of Plant Industry; and T. R. Fasulo, Entomology and Nematology Department, Insititue of Food and Agricultural Sciences, University of Florida, Gainesville, FL.

The Institute of Food and Agricultural Sciences (IFAS) is an Equal Employment Opportunity - Affirmative Action Employer authorized to provide research, educational information and other services only to individuals and institutions that function without regard to race, creed, color, religion, age, disability, sex, sexual orientation, marital status, national origin, political opinions or affiliations. For information on obtaining other extension publications, contact your county Cooperative Extension Service office. Florida Cooperative Extension Service / Institute of Food and Agricultural Sciences / University of Florida / Larry R. Arrington, Interim Dean 
A few flies were trapped in New Guinea but it is unlikely to be established there. Occasional flies are trapped in the Austral and Society Islands and New Caledonia in the Pacific. Twice detected on Easter Island, but eradicated (White and Elson-Harris 1994).

\section{Life History}

Unlike several of the other most important fruit fly pests, $B$. tryoni does not breed continuously but passes the winter in the adult stage. The total life cycle requires two to three weeks in summer and up to two months in the fall. Adult females live many months, and four or five overlapping generations may develop annually. Adult females, after passing through a two-week pre-oviposition stage following emergence from the pupae, deposit eggs in groups, up to seven eggs per group, in fruit punctures. Females often oviposit in punctures made by other fruit flies such as those of the Mediterranean fruit fly, Ceratitis capitata (Wiedemann), with the result that many eggs often occur in a single cavity. As many as 40 larvae have been found in one peach, and as many as 67 adults have been reared from one apple. Eggs hatch in two to three days under favorable weather conditions. The ensuing larval development may be completed in as little as five days. Pupation normally occurs in the soil. Pupal development requires from a week in summer to a month or more in cooler weather. Adults may live a year or more. Adults feed primarily upon juices of host plants, nectar, and honeydew secreted by various kinds of insects.

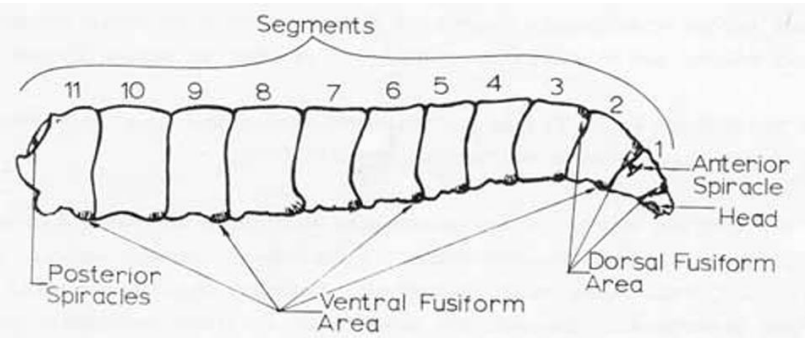

Figure 1. Larva. Credits: Division of Plant Industry

\section{Identification}

Immature stages are similar in appearance to those of other Bactrocera. The adult female is approximately $6 \mathrm{~mm}$ long, has a wing expanse of 10 to $12 \mathrm{~mm}$, and has mostly transparent wings marked with brown. The fly is brown marked with yellow. On the thorax a broad creamy, often pale, dorsal band runs down the scutellum, and there is a well-defined narrow pale yellow stripe on each side. The humeri, or shoulders, are pale yellow, also. The abdomen is constricted at the base, flared in the middle, and broadly rounded at the tip, not counting the ovipositor of the female.

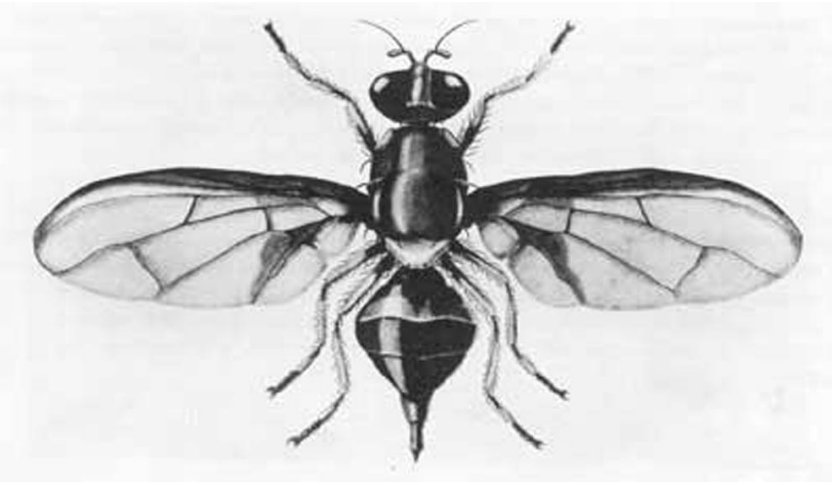

Figure 2. Adult female Queensland fruit fly, Bactrocera tryoni (Froggatt). Credits: Division of Plant Industry

\section{Hosts}

More than 100 species of fruits and vegetables have been recorded as hosts of $B$. tryoni, including grapefruit, sweet orange, Mandarin orange, sour orange, lemon, papaya, guava, mango, peach, mulberry, cashew, loquat, fig, plum, pear, nectarine, apricot, persimmon, apple, quince, sour cherry, tomato, cucumber, and blackberry. Bananas are said to be attacked only when overripe, and other fruits, such as grapes, are attacked only in peak years. Wild hosts include passion- flower, Passiflora spp., and the stoppers, Eugenia spp.

\section{Attractants}

Males attracted to cue lure (White and Elson-Harris 1994).

\section{Selected References}

Anonymous. (1998). Research Report. Fruit Fly Research Centre.

http://www.bio.usyd.edu.au/fruitfly/resdetail.htm (26 December 2001).

Christenson LD, Foote RH. 1960. Biology of fruit flies. Annual Review of Entomology 5: 171-192. 
Oakley RG. 1950, January 30. Fruit flies

(Tephritidae). Manual of Foreign Plant Pest for Fruit Flies, Part 3, p. 167-246.

USDA, Survey and Detection Operations, Plant Pest Control Division, Agr. Research Service.

Anonymous. 1957. Insects not known to occur in the United States. Cooperative Economic Insect Report 7: 1-687. Queensland Fruit fly (Dacus tryoni (Frogg.)), p. 35-36.

White IM, Elson-Harris MM. 1994. Fruit Flies of Economic Significance: Their Identification and Bionomics. CAB International. Oxon, UK. 601 p. 